九州大学学術情報リポジトリ

Kyushu University Institutional Repository

\title{
Factors Affecting Chinese Consumer Awareness and Acceptance of Japanese Rice
}

Wang, Zhigang

School of Agricultural Economics and Rural Development, Renmin University of China

Li, Jiajie

School of Agricultural Economics and Rural Development, Renmin University of China

Zheng, Shi

School of Agricultural Economics and Rural Development, Renmin University of China

Moritaka, Masahiro

Laboratory of Food Marketing and Distribution, Division of Agricultural and Resource

Economics, Department of Agricultural and Resource Economics, Faculty of Agriculture, Kyushu University

他

https://doi.org/10.5109/27379

出版情報: 九州大学大学院農学研究院紀要. 58 (2)，pp.459-465，2013-09. Faculty of Agriculture， Kyushu University

バージョン :

権利関係 : 


\title{
Factors Affecting Chinese Consumer Awareness and Acceptance of Japanese Rice
}

\author{
Zhigang WANG ${ }^{1}$, Jiajie LI $^{1}$, Shi ZHENG ${ }^{1}$, Masahiro MORITAKA ${ }^{2 *}$ \\ and Susumu FUKUDA ${ }^{2}$
}

\author{
Laboratory of Food Marketing and Distribution, Division of Agricultural and Resource Economics, \\ Department of Agricultural and Resource Economics, Faculty of Agriculture, \\ Kyushu University, Fukuoka 812-8581, Japan \\ (Received April 26, 2013 and accepted May 9, 2013)
}

\begin{abstract}
This paper investigated consumers' awareness and acceptance of the Japanese rice in Beijing area. Data was collected through a face-to-face interview survey to consumers in six supermarkets in Beijing during December 2008 and January 2009. A total sample of 400 consumers participated in the survey. Data included socio-demographics and questions regarding their cognition, attitude and purchasing behavior on Japanese rice. The results obtained from the survey showed that consumers had relatively low cognition and acceptance on Japanese rice and only $14.8 \%$ of the respondents had purchasing experience on Japanese rice. Although Japanese rice maintained high quality property, high price, lack of purchasing motivation, and sufficient and satisfying rice supply from domestic market obstructed the good sales record of Japanese rice in China. The bivariate probit model results showed that consumer's gender, education level, monthly expense on foods, and time pressure significantly positively affected the consumers' cognition level on Japanese rice, whileconsumers' age and quantity concern degree negatively and significantly affected their awareness. As far as the purchasing behavior of consumers on Japanese rice, consumer's gender, education level, family size, quantity and nutrition concern degreesignificantly and positively affected the consumers' purchasing behavior on Japanese rice, while their monthly expense on food and quality concern degree negatively affected their purchase significantly. This finding provides contribution to strengthening marketing strategy that increase awareness and acceptance of Japanese rice in Chinese rice market.
\end{abstract}

Key words: acceptance, awareness, china, consumer, Japanese rice

\section{INTRODUCTION}

Since arice trade agreement between China and Japan was signed in 2007, Japanese rice has been exported to Chinese market for almost five years. High labor costs in Japan and high tariff level resulted in the price of Japanese rice were over 15 times higher than domestic rice, i.e. a rice with brand name of "Koshihikari" has a price at $99 \mathrm{RMB} / \mathrm{kg}$, and Miyagi's rice called "Love at first sight" costs $94 \mathrm{RMB} / \mathrm{kg}$. Japanese rice was regarded as a luxurious food for Chinese families. However, we found that Japanese rice in the Chinese supermarket has maintained a good sales record during the past four years. For example, in January 2009, 24 tons of Japanese rice was sold out quickly. This phenomenon has attracted our attention and interest to investigate the extent of Chinese consumers' awareness and acceptability of Japanese rice.

Consumers' purchase behavioron foods has been well studied (Ippolito et al., 1990; Gila et al., 2000; Sedjo and Swallow, 2002; Soregarol et al., 2003; Cranfield and Magnusson, 2003; Matsumoto et al., 2004; Wu and Fu, 2007; Yang and Wang, 2010). Many researchers have analyzed how different demographic characteristics of

School of Agricultural Economics and Rural Development, Renmin University of China, Beijing 100872, China

${ }^{2}$ Laboratory of Food Marketing and Distribution, Division of Agricultural and Resource Economics, Department of Agricultural and Resource Economics, Faculty of Agriculture, Kyushu University, Fukuoka 812-8581, Japan

* Corresponding author(E-mail: m-moritaka@agr.kyushu-u. ac.jp) consumers (such as age, gender, income, education level, race, family size, region, etc) influence their cognition and acceptability for the certain food products in the market (Gao, 1993; Buzby et al., 1995; Thompson et al., 1998). The research on Chinese consumer's awareness and purchase behavior mainly focused on food safety aspects (Wang, 2003; Zhang et al., 2004; Zhou, 2004; Chen, 2006; Zeng et al., 2007). Li and Guo (2007) studied the cognition and purchase behavior of consumers in Nanjing city of China on safe rice and showed that consumers' education level, household income, and cognition of safe rice played a significant role on their purchase decision on safe rice. However, there are as yet few studies which focused on rice specifically on imported Japanese rice. The scarcity of empirical studies concerning purchase behavior on Japanese rice and its relevance for market justify addressing this as a research topic.

The objectives of this study were to identify the situation of Chinese consumers' cognition and acceptance on Japanese rice and to analyze the factors that significantly affected their purchase behavior.

\section{METHODS}

\section{Data collection}

The data was collected through a questionnaire survey in Beijing conducted between December 2008 and January 2009. Respondents were recruited through face-to-face interview from random consumers in six supermarkets in Haidian District, Beijing. A total of 420 consumers participated in the survey and 400 valid 
questionnaires were obtained. Data collected, in order, included: consumer characteristics, consumer's purchasing behavior on rice and factors affecting this behavior, and consumer's awareness, attitudes and perceptions toward Japanese rice.

The survey collected data concerning consumers' purchasing behavior. Respondents were first asked their rice purchase frequency and place. And then they were required to rate four characteristics - quantity, nutrition, price and quality and safety - according to their importance affecting food purchasing decision making, andeight characteristics- price, freshness, washing-free, appearance, taste, nutrition, brandand safety- according to their level of importance in purchasing rice, specifically. Consumers' awareness, attitude and purchasing behavior of Japanese rice in the domestic market were then measured. The rate of consumers' awareness extent of Japanese rice was based on three levels of "know it well", "know", and "not familiar". And their attitudes toward Japanese rice were based on a four-point Likert scale, including "like", "indifferent", "dislike" and "dislike very much". To understand the relationship between consumers' acceptability and purchasing behavior on Japanese rice, each respondent was requested to indicate whether s/he had purchasing behavior of Japanese rice before and his/her reasons of purchasing or not purchasing it, whether they agree that "Japanese rice is better than domestic rice".

\section{Statistical analysis}

To address the issue of the factors affecting the consumer's awareness and past purchasing behavior of Japanese rice, the current study employed a bivariate probit model. In this study, the bivariate probit model estimated the following joint model of awareness of the Japanese rice (Eq.1) and purchasing behavior of Japanese rice (Eq.2).

$$
\left\{\begin{array}{l}
Y^{*}=X_{1 i} \beta_{1}+\mu_{1 i} \\
Y^{*}=X_{2 i} \beta_{2}+\mu_{2 i}
\end{array}\right.
$$

Where $Y^{*}{ }_{1 i}$ is a continuous latent variable for the indicator variable of whether consumer know about Japanese rice in Chinese market $\left(Y_{1 i}=1\right.$, if $Y^{*}{ }_{1 i}>0$, otherwise 0) and $Y^{*}$ is a continuous latent variable for the indicator variable of whether consumer has ever purchased Japanese rice $Y^{*}{ }_{2 i}=1$, if $Y^{*}{ }_{2 i}>0$, otherwise 0 ). $X_{i}$ denotes a set of independent variables, and $\mu_{1 i}$ and $\mu_{2 i}$ are coefficients for corresponding variables in the models and their relationship followed the bivariate normal distribution.

Table 1. Summary statistics of variables

\begin{tabular}{|c|c|c|c|}
\hline Variable (code) & Definition of variable & Mean & $\begin{array}{l}\text { Standard } \\
\text { deviation }\end{array}$ \\
\hline Whether know about Japanese rice & Yes $=1$, otherwise 0 & 0.21 & 0.41 \\
\hline $\begin{array}{l}\text { Whether consumer has ever purchased } \\
\text { Japanese rice }\end{array}$ & Yes $=1$, otherwise 0 & 0.15 & 0.36 \\
\hline Gender & Male $=1$, female $=0$ & 0.49 & 0.51 \\
\hline Age & $30=1,31-49=2,50=3$ & 1.62 & 0.61 \\
\hline Education & $\begin{array}{l}\text { Primary and below=1, Secondaryschool and high } \\
\text { school=2, College/university }=\text {, Graduate school and } \\
\text { above }=4\end{array}$ & 2.50 & 0.80 \\
\hline Monthly food expenditure (EXP) & $\begin{array}{l}<500=1,500-999=2,1000-1499=3,1500-1999=4 \\
2000-2499=5,2500-2999=6,3000=7\end{array}$ & 3.78 & 0.95 \\
\hline Life pressure (PRESSURE) & $\begin{array}{l}\text { No pressure }=0 \text {, a little bit pressure }=1 \text {, some } \\
\text { pressure }=2 \text {, a lot of pressure }=3 \text {, huge pressure }=4\end{array}$ & 2.70 & 1.20 \\
\hline Family size (FAMILY) & $\begin{array}{l}1 \text { person }=1,2 \text { persons }=2,3 \text { persons }=3,4 \text { persons }=4 \text {, } \\
5 \text { persons }=5 \text {, over } 5 \text { persons }=6\end{array}$ & 2.51 & 0.77 \\
\hline Rice category(CATEGORY) & $\begin{array}{l}\text { Long-grained nonglutinous rice }=0 \text {, } \\
\text { Round-grained nonglutinous rice }=1 \text {, }\end{array}$ & 0.82 & 0.38 \\
\hline Rice purchase frequency (FREQUENCY) & $\begin{array}{l}\text { Once or twice per month }=1 \text {, once or twice per } \\
\text { week }=2 \text {, three or four times per week }=3\end{array}$ & 1.77 & 0.49 \\
\hline Quantity concern (QUANTITY) & $\begin{array}{l}\text { Very weak }=1 \text {, weak }=2 \text {, normal }=3 \text {, strong }=4 \text {, } \\
\text { very strong }=5\end{array}$ & 3.29 & 1.03 \\
\hline Price concern (PRICE) & $\begin{array}{l}\text { Very weak }=1 \text {, weak }=2 \text {, normal }=3 \text {, strong }=4 \text {, } \\
\text { very strong }=5\end{array}$ & 3.76 & 1.05 \\
\hline Quality concern (QUALITY) & $\begin{array}{l}\text { Very weak }=1 \text {, weak }=2 \text {, normal }=3 \text {, strong }=4 \text {, } \\
\text { very strong }=5\end{array}$ & 4.13 & 1.01 \\
\hline Nutrition concern (NUTRITION) & $\begin{array}{l}\text { Very weak }=1 \text {, weak }=2 \text {, normal }=3 \text {, strong }=4 \text {, } \\
\text { very strong }=5\end{array}$ & 3.95 & 0.97 \\
\hline
\end{tabular}




$$
\begin{aligned}
& E\left(\mu_{1 i}\right)=E\left(\mu_{2 i}\right)=0 \\
& \operatorname{Var}\left(\mu_{1 i}\right)=\operatorname{Var}\left(\mu_{2 i}\right) \\
& \operatorname{Cov}\left(\mu_{1 i}, \mu_{2 i}\right)=\rho
\end{aligned}
$$

The joint probability density functions of $\mathrm{Y}_{1 \mathrm{i}}$ and $\mathrm{Y}_{2 \mathrm{i}}$ meet the following equation:

$$
\begin{aligned}
& \operatorname{Pr}\left(Y_{1 i}=1, Y_{2 i}=1\right)=\phi_{2}\left(X_{1 i} \beta_{1}, X_{2 i} \beta_{2}, \rho\right) \\
& \operatorname{Pr}\left(Y_{1 i}=1, Y_{2 i}=0\right)=\phi\left(X_{1 i} \beta_{1}\right)-\phi_{2}\left(X_{1 i} \beta_{1}, X_{2 i} \beta_{2}, \rho\right) \\
& \operatorname{Pr}\left(Y_{1 i}=0, Y_{2 i}=1\right)=\phi\left(X_{2 i} \beta_{2}\right)-\phi_{2}\left(X_{2 i} \beta_{1}, X_{2 i} \beta_{2}, \rho\right) \\
& \operatorname{Pr}\left(Y_{1 i}=0, Y_{2 i}=0\right) \\
& \quad=1-\phi\left(X_{1 i} \beta_{1}\right)-\phi\left(X_{2 i} \beta_{2}\right)-\phi_{2}\left(X_{2 i} \beta_{1}, X_{2 i} \beta_{2}, \rho\right)
\end{aligned}
$$

Where $\phi(X i)$ is a function with univariate normal distribution, and $\phi_{2}\left(X_{i}\right)$ follows bivariate normal distribution containing the parameter $\rho$.

The analysis included the following twelve independent variables: gender, age, education level; household monthly food expenditure, life pressure, family size; rice purchasing category, rice purchasing frequency; the extent of caring about the food quantity, price, quality, and nutrition aspects during purchasing foods. The specific categories used and their mean and standard deviation are shown in Table 1.

\section{RESULTS AND DISCUSSION}

\section{Consumers' socio-demographic profile}

The socioeconomic characteristics of the sample are presented in Table 2. Nearly half of the sample of consumers $(n=400)$ were women $(50.8 \%), 70.5 \%$ were married, and $68.8 \%$ lived in rural areas, indicating most of the respondents had rice-purchasing behavior. 93.5\% of the respondents were less than 50 years old. Over half of the respondents had higher education (college or university degree) (59.2\%), whereas $26.3 \%$ had secondary school education, and $14.5 \%$ primary school education. $97 \%$ of the respondents had jobs and their monthly expense on foods mainly stayed at average level in

\begin{tabular}{|c|c|c|}
\hline Characteristics & Category & Percent (n) \\
\hline Female respondents & & $50.8(203)$ \\
\hline Married respondents & & $70.5(282)$ \\
\hline Living in the rural area & & $68.8(275)$ \\
\hline \multirow[t]{3}{*}{ Age } & $<30$ & $45.0(180)$ \\
\hline & $30-50$ & $48.5(194)$ \\
\hline & $>50$ & $6.5(26)$ \\
\hline \multirow[t]{3}{*}{ Education levels } & Primary & $14.5(58)$ \\
\hline & Secondary & $26.3(105)$ \\
\hline & College/university & $59.2(237)$ \\
\hline Average expense on foods & 500-999 & $5.0(20)$ \\
\hline \multirow[t]{4}{*}{ (RMB/month) } & $1000-1499$ & $34.0(136)$ \\
\hline & $1500-1999$ & $46.8(187)$ \\
\hline & $2000-2499$ & $8.8(35)$ \\
\hline & $\geq 2500$ & $5.4(22)$ \\
\hline \multirow{5}{*}{$\begin{array}{l}\text { Family size } \\
\text { (number of household) }\end{array}$} & 1 & $5.5(22)$ \\
\hline & 2 & $47.0(188)$ \\
\hline & 3 & $40.8(163)$ \\
\hline & 4 & $4.5(18)$ \\
\hline & 5 & $2.2(9)$ \\
\hline \multirow[t]{3}{*}{ Purchasing decision-making power } & Self-determination & $66.0(264)$ \\
\hline & Spouse-determination & $21.0(84)$ \\
\hline & Codetermination & $13.0(52)$ \\
\hline \multirow[t]{5}{*}{ Health status } & Excellent & $14.8(59)$ \\
\hline & Good & $23.2(93)$ \\
\hline & Normal & $48.8(195)$ \\
\hline & $\mathrm{Bad}$ & $9.5(38)$ \\
\hline & Very bad & 3.7 (15) \\
\hline
\end{tabular}
Beijing: 34\% spent 1000-1499 RMB per month on food consumption and 46.8\% spent 1500-1999 RMB/month. $87.8 \%$ of the respondents had a family size of $2-3$ members, and $66.0 \%$ could make their own purchasing decision. Most of the respondents (86.8\%) thought they had good health status.

Table 2. Socio-demographic profile of respondents $(n=400)$ 
Table 3. Information on respondents rice-purchasing behavior $(n=400)$

\begin{tabular}{|c|c|c|}
\hline Characteristics & Category & Percent (n) \\
\hline \multirow[t]{3}{*}{ Frequency on rice purchase } & 3-4 times/week & $2.8(11)$ \\
\hline & 1-2 times/week & $70.8(283)$ \\
\hline & $1-2$ times/month & $26.3(105)$ \\
\hline \multirow[t]{5}{*}{ Purchasing place } & Supermarket & $75.0(300)$ \\
\hline & Fresh market & $10.5(42)$ \\
\hline & Wholesale market & $11.0(44)$ \\
\hline & Street vendor & $0.5(2)$ \\
\hline & Door-to-Door & $0.5(2)$ \\
\hline \multirow[t]{2}{*}{ Purchasing rice type } & Round-grained nonglutinous rice & $82.0(328)$ \\
\hline & Long-grained nonglutinous rice & $18.0(72)$ \\
\hline \multirow[t]{8}{*}{ Factors influencing rice purchasing decision } & Price & $65.0(260)$ \\
\hline & New and fresh & $12.0(48)$ \\
\hline & Nutrition & $9.0(36)$ \\
\hline & Safety & $8.0(32)$ \\
\hline & Taste & $2.5(10)$ \\
\hline & Brand & $2.0(8)$ \\
\hline & Appearance & $1.0(4)$ \\
\hline & Washing-free & $0.5(2)$ \\
\hline
\end{tabular}

\section{Consumers' rice purchasing behavior}

Consumers' behavior on purchasing rice was investigated in the survey. As shown in Table $3,70.8 \%$ of the respondents purchased rice 1 to 2 times per week. This indicates that current Chinese consumers' rice purchasing behavior have changed --- from the traditional ways through purchasing large amount of rice one time and storing it with a long time period, to the style of treating rice like other fast consuming foods through increasing purchasing frequency but decreasing the quantity at each shopping time. Food convenience and freshness have become the main characteristics contributing to their purchasing decision making. Japanese rice was usually packed with 2 kilograms per bag which met the small amount requirement under the current shopping habit. Our survey showed that $75 \%$ of the respondents purchased rice from supermarkets, indicating that most of our respondents had access to the Japanese rice since supermarket is their main purchasing location.

In the survey, $82 \%$ of the consumers preferred to the round-grained nonglutinous rice, indicating that Japanese rice belonging to the round-grainedtype meets most of the consumers' taste. Consumers were asked to rate factors which influenced their rice-purchasing behavior, $65 \%$ of the respondents chose "price" as the first consideration factor, $12 \%$ and $9 \%$ of the respondents considered about their "freshness" and "nutrition", and only 8\% cared about the "safety" property, which was different from the caring situation for the most of the food. This was because that firstly, in Chinese market, rice maintains a stable quality with few safety issues; secondly, rice is a principle food in China with large consumption, consumers have to consider more about the price. Since price was the first factor consideration when Chinese consumers purchase rice, the sales of Japanese ricewith higher price might get affected.

\section{Consumers' cognition, acceptance and willingness to pay for Japanese rice}

Table 4 shows consumer awareness and attitude toward Japanese rice. The results illustrate, of all the consumers interviewed, $78.7 \%$ of the respondents were never aware of the Japanese rice at Chinese market and $69.5 \%$ were not familiar with the information of Japanese rice, which indicate that during the past four years, Chinese consumers still had relatively low cognition and awareness on Japanese rice, partly due to the limited supermarkets providing Japanese rice. In terms of consumer's attitude toward Japanese rice, we found that only $3.5 \%$ of the respondents expressed their preference toward Japanese rice, 35.8\% didn't show their like/dislike opinion, while the rest of the respondents (60.7\%) expressed a negative attitude towards it. Consumers' attitude toward Japanese rice directly influenced their purchasing behavior. According to our survey, only $14.8 \%$ of the respondents had purchasing experience on Japanese rice.

There are three reasons for the situation of few consumers purchasing Japanese rice. Firstly, high price of Japanese rice significantly affected consumers' willingness to pay for it. As reported above, price was the first factor that influenced Chinese consumers' purchasing decision on rice. Our study showed that among the respondents who never purchased Japanese rice, 53.1\% of them rated the "high price" as the first factor affecting their decision. Compared to current market price nearly $100 \mathrm{RMB} / \mathrm{kg}, 85 \%$ of the consumers showed that they were willingness to pay for Japanese rice if they were 
Table 4. Consumers' cognition, acceptance and willingness to pay for Japanese rice ( $n=400)$

\begin{tabular}{|c|c|c|}
\hline Characteristics & Category & Percent(n) \\
\hline \multirow[t]{2}{*}{ Whether know about Japanese rice } & Yes & $21.3(85)$ \\
\hline & No & $78.7(315)$ \\
\hline \multirow[t]{3}{*}{ Cognition on Japanese rice } & Know it well & $5.5(22)$ \\
\hline & Know & $25.0(100)$ \\
\hline & Not familiar & $69.5(278)$ \\
\hline \multirow[t]{4}{*}{ Attitude toward Japanese rice } & Like & $3.5(14)$ \\
\hline & Indifferent & $35.8(143)$ \\
\hline & Dislike & $21.5(86)$ \\
\hline & Dislike very much & $39.2(157)$ \\
\hline Consumers who had purchased Japanese rice & & $14.8(59)$ \\
\hline \multirow[t]{3}{*}{ Agree with "Japanese rice is better than domestic rice" } & All respondents & $7.8(31)$ \\
\hline & Respondents who had eaten Japanese rice & $27.1(16)$ \\
\hline & Respondents who had not eaten Japanese rice & $4.4(15)$ \\
\hline \multirow{5}{*}{$\begin{array}{l}\text { Reasons of purchasing Japanese rice (only for } 59 \\
\text { respondents who had purchasing experience) }\end{array}$} & Recommendation from sellers & $49.2(29)$ \\
\hline & Influenced by others & $22.0(13)$ \\
\hline & Worthwhile to purchase & $15.3(9)$ \\
\hline & Purchase as a gift & $5.1(3)$ \\
\hline & Others & $8.5(5)$ \\
\hline \multirow{3}{*}{$\begin{array}{l}\text { Reasons of not purchasing Japanese rice (only for } 341 \\
\text { respondents who don't have purchasing experience) }\end{array}$} & High price & $53.1(181)$ \\
\hline & Know little about it & $35.2(120)$ \\
\hline & Not necessary & $29.0(99)$ \\
\hline \multirow[t]{3}{*}{ Willingness to pay (RMB/kg) } & 10 & $85.0(340)$ \\
\hline & 15 & $10.5(42)$ \\
\hline & 20 & 4.5 (18) \\
\hline
\end{tabular}

offered at a lower price (10 RMB/kg), which was even 2 times higher than the price of the domestic rice (Table 4). Secondly, the motivation of purchasing Japanese rice lack of continuity. Among the consumers who had purchasing experience, their purchasing motivation mainly came from the recommendations from sellers or others $(71.2 \%)$, or as a gift resource (5.1\%). Based on that, we would not be able to know whether they would continue to buy it or not later. This could explain why Japanese rice could not keep the quick sold-out record. Thirdly, sufficient and satisfying rice supply from the domestic market already could meet the needs from consumers. According to our survey, most of the respondents did not think Japanese rice was better than domestic rice. Among the respondents who had eaten Japanese rice, only $27.1 \%$ of them thought Japanese rice was better than domestic rice, while for respondents who had not eaten it, even only $4.4 \%$ agreed with that. This indicates again that Chinese consumers did not have strong motivation for purchasing Japanese rice.

Factors influencing consumer's awareness and acceptance of Japanese rice

This study analyzed 400 consumers' data by bivari- ate probitmodel and explored factors which significantly affected the consumer's awareness and acceptance of Japanese rice. Twelve factors were selected as independent variables and the bivariate probitmodel results were shown in Table 5.

According to the results, consumer's gender, education level, monthly expense on foods, and time pressure significantly positively affected the consumers' cognition level on Japanese rice, whileconsumers' age and quantity concern degree negatively and significantly affected their awareness. These results were fit for our anticipation. Consumers with higher education level, higher monthly expense and limited relax time stood for the middle-class groups who own more opportunity to access Japanese rice in the supermarket at the higher consumption level. Relatively speaking, women, especially housewives were more caring about the cost performance on grocery shopping than men. Meanwhile, women, aged people and consumers concerning more on the quantity property were more realistic and relatively lack of the inclination to learn the new things.

As far as the purchasing behavior of consumers on Japanese rice, consumer's gender, education level, family size, quantity and nutrition concern degreesignifi- 
Table 5. Bivariate probit model of awareness and acceptability of Japanese rice ( $n=400)$

\begin{tabular}{|c|c|c|c|c|}
\hline Variables & Coefficients & Standard error & $Z$ value & $\mathrm{P}>|\mathrm{Z}|$ \\
\hline \multicolumn{5}{|c|}{ Whether know about Japanese rice } \\
\hline Gender & 3.4474 & 0.4633 & 7.44 & $0.000^{* *}$ \\
\hline Age & -0.9841 & 0.2271 & -4.33 & $0.000^{* *}$ \\
\hline Education & 0.4742 & 0.1649 & 2.88 & $0.004^{* *}$ \\
\hline EXP & 0.3041 & 0.1114 & 2.73 & $0.006^{* *}$ \\
\hline PRESSURE & 0.4517 & 0.1124 & 4.02 & $0.000^{* *}$ \\
\hline FAMILY & -0.2598 & 0.1466 & -1.77 & $0.076^{*}$ \\
\hline CATEGORY & -0.2596 & 0.2391 & -1.09 & 0.278 \\
\hline FREQUENCY & -0.1989 & 0.1859 & -1.07 & 0.285 \\
\hline QUANTITY & -0.4199 & 0.1469 & -2.86 & $0.004^{* *}$ \\
\hline PRICE & -0.1093 & 0.1292 & -0.85 & 0.397 \\
\hline QUALITY & 0.1920 & 0.1279 & 1.50 & 0.133 \\
\hline NUTRITION & -0.0949 & 0.1334 & -0.71 & 0.477 \\
\hline _cons & -2.8225 & 1.0678 & -2.64 & 0.008 \\
\hline \multicolumn{5}{|c|}{ Whether consumer has ever purchased Japanese rice } \\
\hline Gender & -3.2410 & 0.5565 & -5.82 & $0.000^{* *}$ \\
\hline Age & -0.2964 & 0.2376 & -1.25 & 0.212 \\
\hline Education & 0.8563 & 0.2079 & 4.12 & $0.000^{* *}$ \\
\hline EXP & -0.6675 & 0.2170 & -3.08 & $0.002 * *$ \\
\hline PRESSURE & -0.0631 & 0.0996 & -0.63 & 0.526 \\
\hline FAMILY & 0.6256 & 0.1753 & 3.57 & $0.000^{* *}$ \\
\hline CATEGORY & -0.1060 & 0.2703 & -0.39 & 0.695 \\
\hline FREQUENCY & -0.2129 & 0.2205 & -0.97 & 0.334 \\
\hline QUANTITY & 1.5663 & 0.2532 & 6.19 & $0.000 * *$ \\
\hline PRICE & -0.0615 & 0.1261 & -0.49 & 0.626 \\
\hline QUALITY & -0.6333 & 0.1483 & -4.27 & $0.000^{* * *}$ \\
\hline NUTRITION & 0.7499 & 0.1900 & 3.95 & $0.000 * *$ \\
\hline _cons & -5.9313 & 1.6427 & -3.61 & 0.000 \\
\hline Rho & -0.7870 & 0.2117 & 3.72 & 0.000 \\
\hline Likelihood-ratio test of rho $=0$ & & & $\operatorname{chi} 2(1)=9.5609$ & Prob $>$ chi $2=0.0020$ \\
\hline Number of obs & & & 400 & \\
\hline Wald chi2(24) & & & 135.32 & \\
\hline Prob> chi2 & & & 0.000 & \\
\hline Log likelihood & & & -194.968 & \\
\hline
\end{tabular}

Note: Statistical significance is indicated at $* * 1 \%$ and $* 10 \%$ levels.

cantly and positively affected the consumers' purchasing behavior on Japanese rice, while surprisingly, their monthly expense on food and quality concern degree negatively affected their purchase significantly. Firstly, similar to the explanation above, male consumers with higher education level were more aware of Japanese rice and also more intended to buy it. Secondly, the families with more membersand consumers concerning more about the food quantity property usually maintained a higher frequency for the grocery shopping than families with one or two people, which increased the opportunity to purchase Japanese rice. Meanwhile, Japanese rice with good nutrition property appealed to the groups who cared about the nutrition aspect. Thirdly, the reason that consumers with high expense on food would less intend to purchase Japanese rice was mainly because of its high price, which might further increase the burden of the life. Finally, it was surprising that consumers who concern more about the quality aspect of rice would less intend to purchase Japanese rice. Our explanation is in Chinese market, there did exist quite a few brands of rice maintaining high quality similar to Japanese rice, such as the rice originally from the northeast part of China, which could act as a replacement of Japanese rice with good quality characteristics. 


\section{CONCLUSIONS}

This case study investigated the consumers' awareness and acceptance or Japanese rice at Beijing area. The results obtained from the survey showed that consumers had relatively low cognition and acceptance on Japanese rice and only $14.8 \%$ of the respondents had purchasing experience on Japanese rice. Although Japanese rice maintained high quality property, high price, lack of purchasing motivation, and sufficient and satisfying rice supply from domestic market obstructed the good sales record of Japanese rice in China. We used the bivariate probit modelto explore the factors which significantly affected consumers' awareness and purchasing behavior. The results showed that consumer's gender, education level, and monthly expense on foods, and time pressure significantly positively affected the consumers' cognition level on Japanese rice, whileconsumers' age and quantity concern degree negatively and significantly affected their awareness. As far as the purchasing behavior of consumers on Japanese rice, consumer's gender, education level, family size, quantity and nutrition concern degreesignificantly and positively affected the consumers' purchasing behavior on Japanese rice, while their monthly expense on food and quality concern degree negatively affected their purchase significantly. This finding provides contribution to strengthening marketing strategy that increase awareness and acceptance of Japanese rice in Chinese rice market.

\section{ACKNOWLEDGEMENTS}

The paper was supported by Major Research Plan of the National Social Science Foundation (grant No. 11\& ZD052), Foreign Publishment Plan, the Fundamental Research Funds for the Central Universities, and the Research Funds of Renmin University of China (No. 10XNK092, 12XNQ068, 12XNQ069), and JSPS KAKENHI Grant Number 23248039.

\section{REFERENCES}

Buzby, J. C., R. C. Ready, and J. R. Skee 1995 Contingent valuation in food policy analysis: a case study of a pesticide-residue risk reduction, Journal of Agricultural and Applied Economics, 27(2): 615-623

Chen, Z. Y. 2006 Ago-foods free of hazardous elements: consumers' willingness to pay and their purchase behavior, and influencing factors: a study in Beijing, Journal of Agrotechnical Economics, 1: 68-75

Cranfield, J. A. L., and E. Magnusson 2003 Canadian consumers' willingness to pay for pesticide free food products: an ordered probitanalysis. International Food and Agribusiness Management Review, 6(4): 114-128

Gao, X. M., R. Anderson, and J. Y. Lee 1993 A structural latent variable approach to modeling consumer perception: a case study of orange juice. Agribusiness, $\mathbf{9}(4)$ : 317-324

Gila, J. M., A. Gracia, and M. Sanchez 2000 Market segmentation and willingness to pay for organic products in Spain. International Food and Agribusiness Management Review, 3(1): 207-226

Ippolito, P. M., and A. D. Mathios 1990 Information, advertising and health choice. Rand Journal of Economics, 21(3): 59-80

Li, M. L., and H. D. Guo 2007 Consumers' cognition and purchasing behavior on rice safety: a case study of consumers in Nanjing. Journal of Northwest A\&F University, 7: 66-71

Matsumoto, S. 2004 Consumers'responses to front vs. back package GM labels in Japan. Journal of Agricultural \& Food Industrial Organization, 2(1): 5

Sedjo, R. A., and S. K. Swallow 2002 Voluntary eco-labeling and the price premium. Land Economics, 78(2): 272-284

Soregarol, C., S. Boccalett, and D. Moro 2003 Consumer' sattitude towards labeled and unlabeled GM food products in Italy. International Food and Agribusiness Management Review, 6(2): $112-127$

Thompson, G. D. 1998 Consumer demand for organic foods: what we know and what we need to know. American Journal of Agricultural Economics, 80(5): 1113-1118

Wang, Z. G., T. Yutaka, S. Fukuda, and S. Kai 2003 Food safety perception and consumption decision: A positive analysis on individuals' consumer in Tainjin City. Journal of the Facultyof Agriculture Kyushu University, 47(2): 469-475

$\mathrm{Wu}, \mathrm{J}$., and G. Fu 2007 The effects of brand origin country and made-in country on consumers' product evaluations and purchase intention. Frontiers of Business Research in China, 1(3): 333-350

Yang, D., and X. Wang 2010 The effects of 2-tier store brands' perceived quality, perceived quality, perceived value, brand knowledge, and attitude on store loyalty. Frontiers of Business Research in China, 4(1): 1-28

Zeng, Y. C., W. Xia, and B. Huang 2007 Consumers' perception of green food and its determinants. Consumer Economics, 13(1): $38-42$

Zhang, X. Y., G. Li, and L. Zhang 2004 Chinese consumers' concerns over food safety. China Rural Survey, 1: 14-21

Zhou, Y. H. 2004 The lead in food safe economics and its research dynamic. Modern Economic Research, 8: 25-27 